\title{
Economic Feasibility Analysis of Water-Harvesting Techniques for Mined-Land Reclamation
}

\author{
L. A. Nieves
}

M. H. Marti

July 1981

Prepared for the U.S. Department of Energy under Contract DE-AC06-76RLO 1830

Pacific Northwest Laboratory

Operated for the U.S. Department of Energy

by Battelle Memorial Institute 
NOTICE

This report was prepared as an account of work sponsored by the United States Government. Neither the United States nor the Department of Energy, nor any of their employees, nor any of their contractors, subcontractors, or their employees, makes any warranty, express or implied, or assumes any legal liability or responsibility for the accuracy, completeness or usefulness of any information, apparatus, product or process disclosed, or represents that its use would not infringe privately owned rights.

The views, opinions and conclusions contained in this report are those of the contractor and do not necessarily represent those of the United States Government or the United States Department of Energy.

\author{
PACIFIC NORTHWEST LABORATORY \\ operated by \\ BATTELLE \\ for the \\ UNITED STATES DEPARTMENT OF ENERGY \\ Under Contract DE-ACO6-76RLO 1830
}

\author{
Printed in the United States of America \\ Available from \\ National Technical Information Service \\ United States Department of Commerce \\ 5285 Port Royal Road \\ Springfield, Virginia 22151
}

Price: Printed Copy $\$$

$\therefore$ Microfiche $\$ 3.00$

$\begin{array}{cr}\text { •Pages } & \begin{array}{c}\text { NTIS } \\ \text { Selling Price }\end{array} \\ 001-025 & \$ 4.00 \\ 026-050 & \$ 4.50 \\ 051-075 & \$ 5.25 \\ 076-100 & \$ 6.00 \\ 101-125 & \$ 6.50 \\ 126-150 & \$ 7.25 \\ 151-175 & \$ 8.00 \\ 176-200 & \$ 9.00 \\ 201-225 & \$ 9.25 \\ 226-250 & \$ 9.50 \\ 251-275 & \$ 10.75 \\ 276-300 & \$ 11.00\end{array}$


ECONOMIC FEASIBILITY ANALYSIS OF WATER-HARVESTING TECHNIQUES FOR MINED-LAND RECLAMATION

L. A. Nieves

M. H. Marti

July 1981

Prepared for the U.S. Department of Energy under Contract DE-AC06-76RLO 1830

Pacific Northwest Laboratory

Richland, Washington 99352 


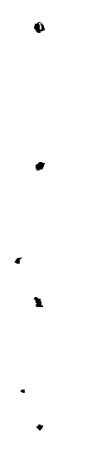




\section{SUMMARY}

The Pacific Northwest Laboratory (PNL) has been field testing a water harvesting, agricultural production system as a means of reclaiming strip-mined land. Though the technical feasibility of the PNL system is becoming increasingly apparent, economic feasibility and legal issues may determine its potential application. The purpose of this study is to explore the economic feasibility of the PNL system and to provide information for use in assessing whether further investigation of water harvesting reclamation techniques. is warranted.

The economic feasibility of the PNL reclamation system hinges on whether or not its net benefits exceed those of conventional reclamation. This preliminary feasibility study assesses the net private benefits of each system using data for the Peabody Coal Company's Kayenta mine on the Black Mesa in Arizona. To compare the alternative reclamation systems, the present value of direct net benefits (income minus production and reclamation costs) is calculated for grazing (conventional reclamation) or for cropping (PNL reclamation). It should be noted that climatic and soil conditions render this area poorly suited to agricultural production. As a result, the findings of this study may not represent PNL system potential on other semi-arid or arid sites.

Three of the PNL system slope treatments have lower estimated total costs than conventional reclamation. The difference is $\$ 3,895 /$ acre for compacted slope, $\$ 3,025 /$ acre for salt-compacted slope and $\$ 2,310 /$ acre for crop-on-slope. These differences constitute a substantial cost advantage for the PNL system on the basis of the present value of land reclamation and maintenance costs.

The PNL system also has advantages based on the estimated value of agricultural production capacity. Even the lowest yield levels considered for alfalfa, corn and pinto beans had higher net present values than grazing. It is recognized, however, that both conventional and PNL reclamation may have nonmarket benefits that are not included in the benefit estimation. These are unlikely to offset the difference between cropping and grazing values, however.

On the basis of this comparison it appears that the PNL system may well be economically attractive and certainly merits serious investigation. However, 
this evaluation of the PNL system rests on several assumptions that will require field tests. While uncertainties regarding feasibility of the PNL system for use on various sites remain, it appears that the system is potentially viable on sites that have as little as 25 to $30 \%$ of the precipitation normally required for crop production. Any future improvements made in the cost/effectiveness of the slope treatments would increase the profitability of the system by making it possible to raise various types of crops and increasing potential yields above those assumed in this study.

Several issues surfaced during this study, most of which must be resolved before the PNL system can be implemented. Perhaps the most important issue is the question of what is successful reclamation under the law. The question of the mining company's liability is another issue which affects the viability of the PNL system. There is also an issue of viability of the PNL system due to physical characteristics of the mining operation and reclaimed land. The quantity of reclaimed land required to constitute a viable farming operation on reclaimed land is unknown. It is unclear what the cost effects would be of the cropping practices required to farm land that consists of usable strips separated by 35 yard wide mounds. In addition, there is the issue of cropland demand in areas where sheepherding or cattle grazing is the major productive activity. 


\section{CONTENTS}

i i i

INTRODUCTION

CONCLUSIONS . . . . . . . . . . . . . 3

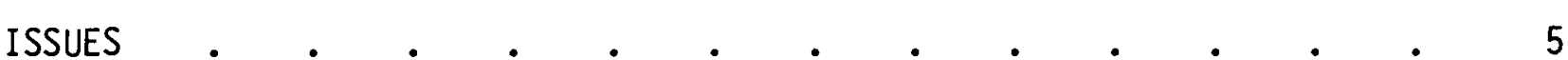

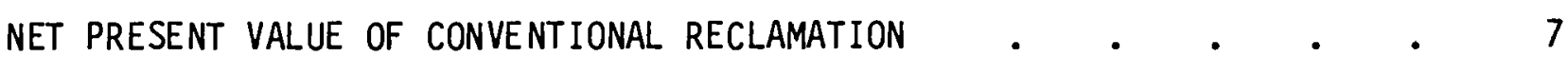

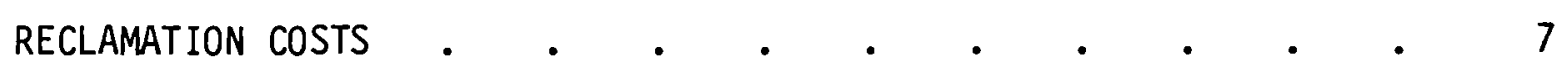

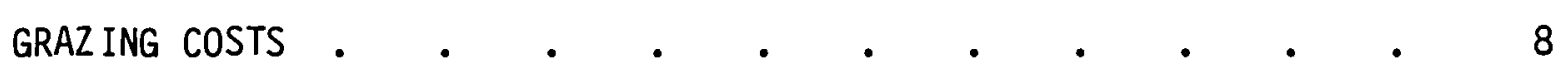

GRAZING INCOME

NET PRESENT VALUE OF GRAZING • • • • • • • • • • 10

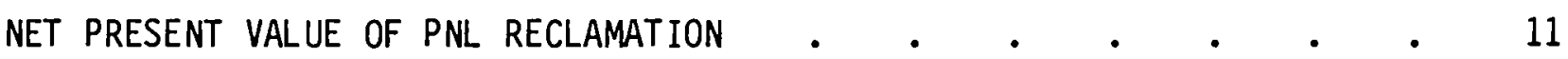

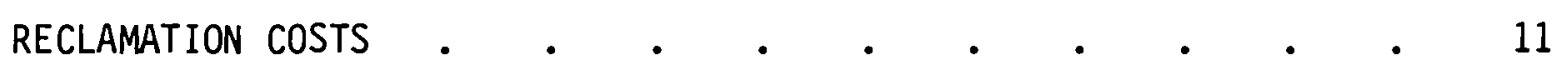

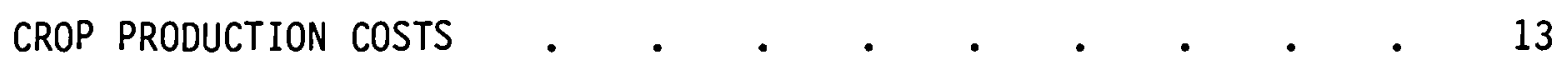

NET PRESENT VALUE OF CROPPING •

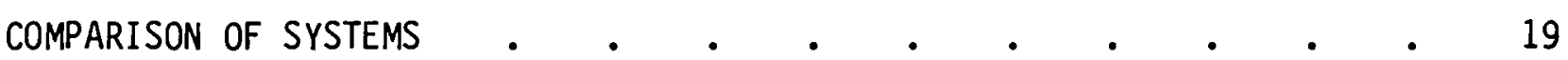

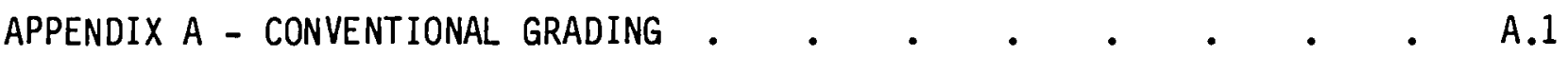

APPENDIX B - GRADING COSTS $\quad$ •

APPENDIX C - PNL GRADING •

APPENDIX D - SLOPE TREATMENT COSTS •

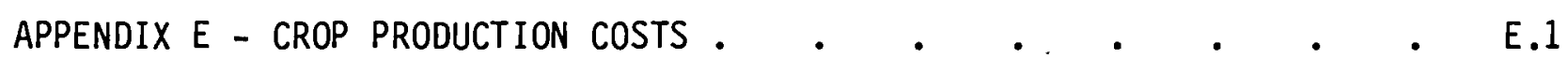

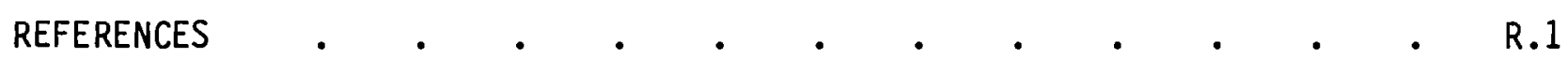

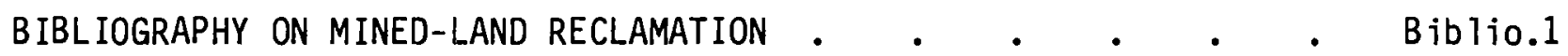





\section{INTRODUCTION}

Since the spring of 1979, the Pacific Northwest Laboratory (PNL) has been field testing a water harvesting, agricultural production system as a means of reclaiming strip-mined land. Though the technical feasibility of the PNL system is becoming increasingly apparent, economic feasibility and legal issues may determine its potential application. The purpose of this study is to compare the net private benefits of conventional reclamation with those of reclamation using the PNL water harvesting system. The comparison is based on the differences between the income and cost streams of the two systems and can be used to assess whether further investigation of water harvesting relamation techniques is warranted.

Currently, federal regulations(a) require that mining companies return disturbed land to its approximate original contours and restore it to a level of productivity at least as great as it originally had. Such reclamation of surface coal mines in the arid West is a difficult task. Because of the adverse weather conditions and poorly developed soil, reclamation has been an uncertain, slow and expensive process. When most successful, the reclamation effort often restores arid land to the status of marginal rangeland.

Reclamation laws at both the state and federal level were enacted in response to perceived public costs due to abandonment of strip-mined land. These costs derive from loss of wildlife habitat, erosion, watershed disruption, and other factors. The reclamation laws shift a portion of the costs previously borne by the public onto mining firms (and ultimately, coal consumers) through the imposition of a reclamation requirement. In imposing the reclamation requirement, there is an implicit assumption made that the least cost method of averting public costs is to restore the land surface to an approximation of its original condition.

In contrast to this approach, the PNL reclamation system takes advantage of the spoil banks created by the mining operation. When the land is recontoured some spoil bank slope is retained to provide water catchment surfaces

(a) Public Law 95-87. "Surface Mining Control and Reclamation Act of 1977." 95th Congress. 
for the trough areas in which all of the topsoil is spread. This creates a water harvesting system permitting agricultural use of approximately $1 / 4$ to $1 / 6$ of the mined acreage.

The economic feasibility of the PNL technique hinges on whether or not its net benefits exceed those of conventional reclamation. This preliminary feasibility study assesses the net benefits of each system using data for the Peabody Coal Company's Kayenta mine on the Black Mesa in Arizona. Field tests of the water catchment system at this site have provided some soil moisture data. Because the site is at relatively high elevation ( 5500 to $6500 \mathrm{ft}$ ), experiences both high and low temperature extremes, and is subject to extended periods of drought, it has one of the harshest arid climates in the West. The climatic conditions, in conjunction with soils that are poorly developed and low in organic matter (Verma, Thames and Mills 1975), render this area poorly suited to agricultural production. As a result, the findings of this study may not represent PNL system potential on other semi-arid or arid sites.

To compare the alternative reclamation systems, the present value of direct net benefits (income minus production and reclamation costs) is calculated for grazing (conventional reclamation) or cropping (PNL reclamation). The cost and income estimates are specific to the Kayenta site in Navajo County, Arizona. In calculating the net present value of each system all costs and prices are converted to 1979 dollars using the Consumer Price Index and a rea 1 discount rate of 4 percent is assumed. In addition to comparing present values, this report points out some issues and problems anticipated if the PNL reclamation system were to be adopted.

The present value calculation for conventional reclamation is presented in the first section of this report, followed by that for the PNL system. In the third section the total cosis and expected incomes with the two basic systems are compared. Details of the slope contours and cost and income calculations are given in the appendices. 


\section{CONCLUSIONS}

On the basis of the system comparison, it appears that the PNL system may well be economically attractive and certainly merits serious investigation. However, this evaluation of the PNL system rests on several assumptions that will require field tests: One of these is the assumption that $50 \%$ of precipitation will run off the slopes and be relatively evenly delivered to crops in the valleys. A second is the assumption of crop yield levels resulting from precipitation alone that are greater than $50 \%$ of normal yields with flood irrigation. Another is that typical crop production methods and average costs apply to a "strip farm." These factors and others such as soil type, climate, and precipitation will determine the relative advantages of the PNL system and conventional reclamation.

While these uncertainties regarding feasibility of the PNL system for use on various sites remain, it appears that the system is potentially viable on sites that have as little as 25 to $30 \%$ of the precipitation normally required for crop production. This is due to the ratio of water collection area to growing area. Any future improvements made in the cost/effectiveness of the slope treatments would increase the profitability of the system by making it possible to raise various types of crops and increasing potential yields above those assumed in this study. 
. 


\section{ISSUES}

Several issues surfaced during this study, most of which must be resolved before the PNL system can be implemented. Perhaps the most important issue is the question of what is successful reclamation under the law. In most states, when the 1 and has been restored to its original contours and vegetation is well established the mining company would be in compliance with the laws. With PNL reclamation options, however, compliance with reclamation laws might require a waiver of requirements since the PNL options do not restore the land to original contours.

Most reclamation laws require revegetation of the mined land to minimize erosion. For the PNL options where there is nothing grown on the slopes to slow water runoff, erosion could possibly be a problem. The severity of the problem depends upon the condition of the soil and the efficiency and maintenance of the scope treatment. Some soils resist erosion better than others, and some slope treatments repel water more effectively than others. Even if erosion were not apparent, the lack of slope vegetation and the possibility of erosion might make it difficult for a mining company to prove that they have successfully reclaimed the land so that they may obtain release of their performance bond.

The question of the mining company's liability is another issue which affects the viability of the PNL system. If a farmer using land reclaimed by the PNL system experienced financial difficulties, he might have to cut the costs of production in order to keep farming. The most likely candidate for cost cutting would be the annual slope maintenance costs. The maintenance operations would have less effect on yield than production costs, but could cut costs significantly. If the annual maintenance of the slopes were discontinued, however, the system might no longer be in compliance with reclamation

law because of erosion or because of substandard crop productivity. This would also be the case if the farmer went out of business or chose to stop farming the land altogether. In either event, would the mining company be required to carry out conventional reclamation?

There is also an issue of viability of the PNL system due to physical characteristics of the mining operation and reclaimed land. The quantity of 
reclaimed land required to constitute a viable farming operation on reclaimed land is unknown. At the Kayenta mine, the Peabody Coal Company plans to mine and reclaim 500 acres per year (Peabody). If $18 \%$ of this land is made productive (valley area), there would be 90 acres of cropland area added each year. The resulting acreage might not reach a viable farm size until several years have passed. In addition, it is unclear what the cost effects would be of the cropping practices required to farm land that consists of usable strips separated by 35 yard wide mounds.

In addition, there is the issue of cropland demand on the Navajo Reservation, where sheepherding is the major productive activity. While there are crops grown on the reservation, the socio-cultural context might impact the viability of the PNL system. One effect of this environment was found on the test plots, where yield data were affected by the ineffectiveness of fences in keeping out sheep. 


\section{NET PRESENT VALUE OF CONVENTIONAL RECLAMATION}

Currently, federal regulations require mining companies to return disturbed land to its approximate original contours and restore it to at least its original land use capability. Therefore, it is assumed in this analys is that Black Mesa land reclaimed with conventional methods would be graded so as to return it to an almost flat contour. Though the reclaimed mine site would not be uniformly flat, this assumption provides a reasonable working representation for the purpose of estimating reclamation costs. To estimate income it is assumed that the revegetated land would be capable of grazing the same number of an imals (assuming controlled grazing practices) as is possible in non-mined areas of the Black Mesa.

\section{RECLAMATION COSTS}

Conventional reclamation involves three types of activities or processes: recontouring of the spoil piles, redistribution of topsoils, and revegetation. The costs of each of these activities are estimated in this section. Because fencing costs are assumed to be equal for either the conventional or the PNL reclamation techniques, they are not included in the analysis.

Grading/leveling costs for recontouring the spoil piles are the largest component of total reclamation cost and are a function of the amount of overburden that is moved. At the Kayenta site, spoil piles average 16 yards in height and 40 yards in width. These dimensions result in an estimate of $9,559 \mathrm{yd}^{3}$ of overburden leveled and shaped per acre of disturbed land (calculations are shown in Appendix A). If 75 percent of the work is done with dozers and 25 percent with scrapers, as estimated by Mr. Hilgedick of the Peabody Coal Company, the weighted average cost of moving one cubic yard of overburden is $\$ 0.82$ (calculations are shown in Appendix B). It follows that the estimated cost of leveling each acre of disturbed land is $\$ 7,840, \$ 0.82$ / $\mathrm{yd}^{3}\left(9,559 \mathrm{yd}^{3} /\right.$ disturbed acre $)=\$ 7,838,38 /$ disturbed acre. Peabody coal cost estimates as high as $\$ 9,000$ to $\$ 12,000$ have been given by Dawson (1980).

The cost of topsoiling is determined mainly by the type of method used and the haulage distance. There are two common methods of topsoiling: stockpiling and direct spread. Unless the haulage distance is more than $1 / 2$ mile (Watts 
1975) the direct spread method is less cost ly because the soil is only loaded and dumped once. The range of cost estimates for the topsoiling operation in the B Tack Mesa area is from $\$ 2000$ (Persse et al. 1977) to $\$ 5000$ (Dawson 1980) per acre. In this study, Dawson's lower bound estimate of $\$ 3000 /$ acre is used. We assume that this represents an approximately 9 in. layer of topsoil or 1210 $y d^{3}$ per acre.

Revegetation of disturbed 1 and at the Kayenta mine site may be the most difficult operation in the whole process. Because of the arid climate and relatively poor soil in the region, re-establishing vegetation requires considerable effort and time. Revegetation must be timed so that newly planted seeds have the greatest chance for successful germination. Once started, the vegetation requires from two to five years to reach its full productive capacity (assuming controlled grazing).

The revegetation process for disturbed land consists of five separate operations: contour disking, seeding, fertilizing, straw mulching, and reworking (top dressing and reseeding two years after initial planting). The costs of these operations at the Kayenta mine site were estimated by Dawson (1980). For the first four operations, costs range from $\$ 375 /$ acre to $\$ 440 /$ acre. The lower of these costs, $\$ 375 /$ acre, was assumed in this analysis. Table 1 summarizes the cost estimates. Since reworking is done in the second year, the cost of $\$ 50 /$ acre was discounted to a present value of $\$ 45 /$ acre. (a) The present value of initial and second year costs are sumed so that the present value estimate for all revegetation costs is $\$ 420 /$ acre.

Combining the grading/leveling cost of $\$ 7840 /$ acre, the topsoiling cost of $\$ 3000 /$ acre and the revegetation cost of $\$ 420 /$ acre produces an estimated present value of reclamation cost at the Kayenta mine of $\$ 11,260 /$ acre. This estimate is slightly lower than the costs estimated by Dawson (1980).

GRAZING COSTS

Currently, the most common use of reclaimed land in the arid West is cattle grazing. In some areas, however, the grazing conditions are so poor that

(a) Assumed real discount rate $=4 \%$. Present value of $\$ 1$ in second year $=$ 0.9246 . Therefore, $(\$ 50 /$ acre $)(\$ 0.9246)=\$ 46.23 /$ acre, rounded to $\$ 45 /$ acre. 
TABLE 1. Revegetation Costs Per Acre (1979\$)

\begin{tabular}{|c|c|c|c|}
\hline Operation & Assumed Cost & $\begin{array}{l}\text { High-Cost } \\
\text { Estimate } \\
\end{array}$ & $\begin{array}{l}\text { Low-Cost } \\
\text { Estimate } \\
\end{array}$ \\
\hline Contour Disking & $\$ 150$ & $\$ 150$ & $\$ 150$ \\
\hline Seeding & 50 & 50 & 50 \\
\hline Fertilizing & 25 & 40 & 25 \\
\hline Straw Mulching & 150 & 200 & 150 \\
\hline Total Initial Cost & 375 & 440 & 375 \\
\hline Total Reworking Cost & 50 & 50 & 50 \\
\hline Present Value of Total Cost & $\$ 420$ & $\$ 485$ & $\$ 420$ \\
\hline
\end{tabular}

grazing is almost impractical. The Black Mesa is such an area. This is evident from the grazing capacity of 550 acres per cow unit, year-long (Department of Interior 1964, pp. 4,5).

In spite of the predominance of sheep grazing in the Black Mesa area, cattle grazing was used in this analys is because rangeland use for cattle grazing is increasing and relatively good cost information is available. In 1979 and 1980 there were about 40,000 head of range cattle in Navajo County (Mayes 1980). To calculate the present value of grazing costs on the Black Mesa the following annual cost estimates are utilized:

(1) Cash costs $=\$ 95 /$ cow in herd

(2) Depreciation $=\$ 37 /$ cow in herd

(3) Replacement (death) $=\$ 9 /$ cow in herd

These costs were suggested by $C$. Robertson, Professor of Farm Management at the University of Arizona, Tucson, Arizona.

Using these assumptions, the estimated cost of grazing cattle is approximately $\$ 140$ per cow in herd $(\$ 95+\$ 37+\$ 9=\$ 141)$. (This is an average cost estimate that includes grazing fees and wages for hired labor.) Since 550 acres are required per cow unit, the grazing cost per acre is $\$ 141 / 550$ acres $=$ $\$ 0.26 / a c r e$. Applying a $4 \%$ real discount rate, the present value of grazing costs for 10 years is $\$ 2.11$ /acre. 
GRAZ ING INCOME

Because of the preliminary nature of this feasibility analysis, the only benefit of conventional reclamation considered is grazing income. In reality there may be nonmarket (external) benefits of restoring native vegetation which have considerable value. These benefits include provision of wildlife habitat, prevention of erosion, restoration of scenic views, etc. The value of these benefits should be accounted for in a complete cost/benefit analysis. This point is discussed further in the "Comparison of Systems" section of this paper.

The grazing income estimate is calculated from the expected annual yield per cow. The following production and price assumptions are used:

(1) Calving percentage $=65$ percent

(2) Calves selling weight: Steers $=356 \mathrm{lb}$, Heifers $=317 \mathrm{lb}$

(3) Selling price for steers and heifers, three year adjusted state average in 1979 do 11 ars $=\$ 57.72 /$ cwt (Mayes 1980, p. 54)

From these estimates an average calves' selling weight of 337 ib is calculated, $(356+317) / 2=336.5 \mathrm{lb}$. Using the calving percentage of 65 percent, the expected yield of one cow would be $220 \mathrm{lb},(337)(0.65)=219.05$. Therefore, the income from grazing cattle would be about $\$ 130 /$ cow in herd, (220) $(\$ 0.5772)=\$ 126.98$. Dividing income per cow by 550 acres produces an income estimate of $\$ 0.23 /$ acre. The present value of this income stream over 10 years is $\$ 1.87 /$ acre.

\section{NET PRESENT VALUE OF GRAZ ING}

If the grazing cost and income estimates calculated above are accurate, grazing is not a breakeven operation on the Black Mesa. Costs exceed income, though the losses incurred are only $\$ 0.03$ /acre annualiy and $\$ 0.24 /$ acre on a present value basis. Since there is considerable uncertainty embodied in the cost and income estimates and in the estimate of required acreage per cow, we assume that grazing is in fact a breakeven operation. 


\section{NET PRESENT VALUE OF PNL RECLAMATION}

Reclamation of spoil banks with the PNL system uses a radically different approach from that of conventional reclamation. Since the PNL system is a water-harvesting technique, it requires that some spoil bank slope be retained for water catchments; thus, the land is not reclaimed to its original contour. While the purpose of conventional reclamation is often to restore the land to its original land use capabilities, the PNL system is designed to restore a portion of the land to a condition exceeding its original land use capability (i.e., changed from use for grazing to use for crop production). Because some 1 and area is dedicated to water catchment, on average, on ly 1/6 of the disturbed land $(a)$ is then available for crop production.

\section{RECLAMATION COSTS}

The grading/leveling costs associated with the PNL system are determined in the same manner as the grading/leveling costs for conventional reclamation, the only difference being the angle of the reclaimed slope. For conventional reclamation it is assumed to be $1 \%\left(0.5729^{\circ}\right.$ angle of repose) while for the PNL system it is $20 \%\left(11.3^{\circ}\right.$ angle of repose). This difference in slope means that less of the overburden requires redistribution from the spoil piles in constructing the PNL system. Calculation of the grading requirements is shown in Appendix C.

The costs of moving overburden to construct the PNL system are estimated from the volume of overburden to be moved (6332 $\left.\mathrm{yd}^{3}\right)$ and the cost per cubic yard, $\$ 0.82$ (calculations shown in Appendix B). This results in an estimated cost for grading/leveling of $\$ 5190$ per acre of disturbed land (6332 $\mathrm{yd}^{3} / \mathrm{acre}$ $\left(\$ 0.82 / \mathrm{yd}^{3}\right)=\$ 5192 /$ acre $)$.

Topsoiling costs are estimated to be $2 / 3$ of costs for conventional reclamation. This cost saving is assumed because the topsoil would be dumped and leveled in a seven-yard-wide strip rather than spread evenly over the entire

(a) $847 \mathrm{yd}^{2} /$ acré of valley area per $4,840 \mathrm{yd}^{2} /$ acre of disturbed land $=$ 0.17 . Therefore, the valley is $1 / 6$ acre per acre of disturbed 1 and $(1 / 6=$ $0.17)$. 
surface as called for in conventional practice. This assumption results in a topsoiling cost estimate of $\$ 2000 /$ acre.

Since the agricultural production potential of the PNL reclamation system depends on water harvesting, slope treatments are used to increase the availability of moisture. Slope treatments should also help to control erosion and weed growth. Though these are the major reasons for using slope treatments, it was not within the scope of this study to ascertain the effectiveness of each slope treatment in accomplishing these goals (see Cluff and Frobel 1978). While there are many different types of slope treatments that mining companies could use, five are considered in this study. These are: 1) crop growth on the slopes, 2) compaction of slopes, 3) salt treatment with compaction of slopes, 4) paraffin treated slopes, and 5) rubber-asphalt treated slopes. Treatments 2 and 3 are currently being tested at the Kayenta mine site. Treatments 4 and 5 are under investigation at a test site in Eastern Washington and Treatment 1 (crop on slope) is a theoretical analysis only.

These slope treatments have a wide range of costs and the details of the cost calculations can be found in Appendix D. The least costly option is compacted slope which has no initial slope treatment cost after grading is complete. All of the slope treatments except crop-on-slope have annual maintenance and periodic retreatment costs as well as the initial construction costs. These are shown in Table 2. Retreatment costs are assumed to occur at the end of ten years. These recurring costs are discounted by $4 \%$ to calculate the present value of all slope treatment costs. Adding slope treatment costs to grading/leveling and topsoiling costs, results in the following total present value estimates for all reclamation cost components:

1. crop-on-slope $=\$ 8,950 /$ acre

2. compacted slope $=\$ 7,365 /$ acre

3. salt-compacted slope $=\$ 8,235 /$ acre

4. paraffin treated slope $=\$ 13,170 /$ acre

5. rubber-asphalt treated slope $=\$ 15,060 /$ acre .

Actual costs of about $\$ 8000 /$ acre for construction of test plots with compacted slopes on the mine site (Constant and Thames 1979) corraborate these cost estimates. 

TABLE 2. Ten-Year Present Value of Initial and Recurring Slope
Treatment Cost Per Acre (1979\$)

\begin{tabular}{|c|c|c|c|c|c|c|}
\hline \multirow[b]{2}{*}{$\begin{array}{c}\text { Slope } \\
\text { Treatment }\end{array}$} & \multirow[b]{2}{*}{$\begin{array}{r}\text { In itia }{ }^{2} \\
\left.\operatorname{Cos}^{b}\right) \\
\end{array}$} & \multicolumn{2}{|c|}{ Maintenance ${ }^{(b)}$} & \multicolumn{2}{|c|}{ Retreatment $^{(b)}$} & \multirow{2}{*}{$\begin{array}{c}\text { Total } \\
\text { Present } \\
\text { Value } \\
\end{array}$} \\
\hline & & Annual & $\begin{array}{r}\text { Present } \\
\text { Value } \\
\end{array}$ & Periodic & $\begin{array}{l}\text { Present } \\
\text { Value } \\
\end{array}$ & \\
\hline Crop-on-s lope & $\$ 1,760$ & 0 & 0 & 0 & 0 & $\$ 1,760$ \\
\hline Compacted & $\$ 0$ & 18 & 146 & 40 & 27 & 175 \\
\hline Salt-Compacted & $\$ 600$ & 30 & 243 & 300 & 203 & 1,045 \\
\hline Paraffin Treated & $\$ 3,600$ & 180 & 1,460 & 1,360 & 919 & 5,980 \\
\hline Rubber-Asphalt & $\$ 5,560$ & 55 & 446 & 2,760 & 1,865 & 7,870 \\
\hline
\end{tabular}

Treated

(a) These costs are in addition to the basic PNL system grading and topsoiling costs of $\$ 7,190 /$ acre.

(b) See Appendix E for cost calculation.

CROP PRODUCTION COSTS

The selection of crops to grow with the PNL water harvesting system is dependent upon the same agronomic and economic factors that affect all crop selections. The major agronomic factors limiting the selection of crops on the Black Mesa are temperature and moisture. Extreme temperatures in combination with limited and variable moisture make it difficult to establish crops and maintain their growth until harvest. The major economic factors limiting crop selection are investment risks and marketing. Because of the large investment some crops require (orchards, vineyards, potatoes, etc.) the risks are too great for such a climate. In addition, the remoteness of the study area from a major population center may make it difficult to market crops due to high transportation costs and the limitations of the local market. Therefore, alfalfa, barley, corn, wheat (crops currently grown in the area), and pinto beans (a possible new addition that could be adapted to the area agronomically and economically) were selected as the crops to be considered in this study.

Appendix $E$ contains crop budget estimates for producing the five crops. Some of the costs will vary with the yield of the crop (alfalfa, corn, pinto beans), but the basic production cost for each crop is: 
(1) Alfalfa-- $\$ 92.37 /$ acre of cropland $+\$ 0.45 /$ ton of yield and a first and sixth year establishment cost of $\$ 132.05 /$ acre of cropland.

(2) Bar ley--\$155.98/acre of cropland.

(3) Corn--\$206.11/acre of cropland $+\$ 3.40 /$ ton of yield.

(4) Pinto Beans-- $\$ 129.77 /$ acre of cropland $+\$ 80.00 /$ ton of yield.

(5) Wheat-- $\$ 159.05 /$ acre of cropland.

It should be noted that these are uncertain estimates because of the lack of farm cost data for the area. The annual crop production cost estimates were estimated by applying machinery cost estimates for Graham County, Arizona (Hathorn 1980), to the appropriate set of cropping operations and machinery usages for each crop. These cost components are combined as liabilities against the farmer's crop income. The production cost estimates include costs of machinery, supplies and labor but exclude land leasing or ownership costs.

\section{CROP INCOMES}

The benefits of using the PNL reclamation system are measured in terms of crop.incomes. In reality incomes will depend upon the climate, the yields, selling prices, the farmer's management ability, etc., but for this preliminary analys is it is assumed that incomes depend solely upon the crop grown, its yield, and price. Factors such as climate and management ability are assumed to be constant. In each case considered it is assumed that only one crop is grown, though crop rotations would be possible if not necessary.

The yields which could actually be realized from growing crops on the Black Mesa with a water harvesting system are unknown. Predicting yields based on annual precipitation is not attempted due to the lack of usable data and the irregularity of precipitation. Yields were estimated using information from a report on irrigated agriculture in the Four Corners Area (Gisser 1979). This report gives high, medium, and low yields, with each corresponding to the volume of water applied. (a) These yield estimates varied depending on the

(a) Full water application in flood irrigation = high yield; $80 \%=$ medium yield; $66.7 \%=10$ yield. Assuming $50 \%$ water runoff on the slopes, the range of growing season precipitation required to deliver water to the valleys equivalent to the high-yield water application rates is a high of 17 inches for alfalfa and a low of 5.5 inches for beans. 
elevation at which the crops were grown. Since the mine site is at about 6,500 feet, it falls in the intermediate elevation group. Unfortunately, all five crops considered in this study are not analyzed for this elevation. The crops analyzed for the intermediate elevation (5,500 to 6,500 feet) are alfalfa, barley, wheat and pinto beans, and for the low elevation (below 5,500 feet) corn. Therefore, the applicability to the study site of the yield estimates for intermediate elevation crops should be fairly good, but less good in the case of yield estimates for corn.

To estimate the yield expected from growing crops with the crop-on-slope method it was assumed that a variable yield would occur (one half of the low yield figure on the top half of the slopes, a low yield on the bottom half, and a medium yield in the valley). The projected yield with the crop-on-slope treatment is generally less than the low yield estimate for the other PNL treatments. This is because the yield from increased area planted is not expected to offset the yield loss due to reduced water collection in the valleys. Table 3 shows all of the yield scenarios. Corn and pinto beans were not analyzed for growth on slopes because of their water requirements and production difficulties on the slopes.

The prices of the commodities (Mayes 1980, Agricultural Marketing Services 1979) were estimated by converting 1977 and 1978 prices to 1979 do 11 ars using the Consumer Price Index. Then a three-year average was taken of prices from 1977 through 1979. These are shown in Table 4. Annual and ten-year present

TABLE 3. Estimated Yields per Acre of Cropland

\begin{tabular}{|c|c|c|c|c|}
\hline Crops & $\begin{array}{l}\text { High Yield } \\
\text { (1b) }\end{array}$ & $\begin{array}{c}\text { Medium Yield } \\
(\mathrm{Ib})\end{array}$ & $\begin{array}{l}\text { Low Yield } \\
\text { (1b) } \\
\end{array}$ & $\begin{array}{c}\text { Variable Yield } \\
\text { (ib) }\end{array}$ \\
\hline Alfalfa & 8,000 & 6,800 & 5,800 & 4,780 \\
\hline Bar ley & 3,300 & 2,700 & 2,250 & 1,900 \\
\hline Corn & 6,500 & 5,400 & 4,500 & not grown \\
\hline Pinto Beans & 1,300 & 1,050 & 900 & not grown \\
\hline Wheat & 3,200 & 2,600 & 2,200 & 1,820 \\
\hline
\end{tabular}

Source: Gisser (1979), pp. 36, 37 . 
TABLE 4. Crop Incomes Per Acre of Cropland Planted (1979\$)

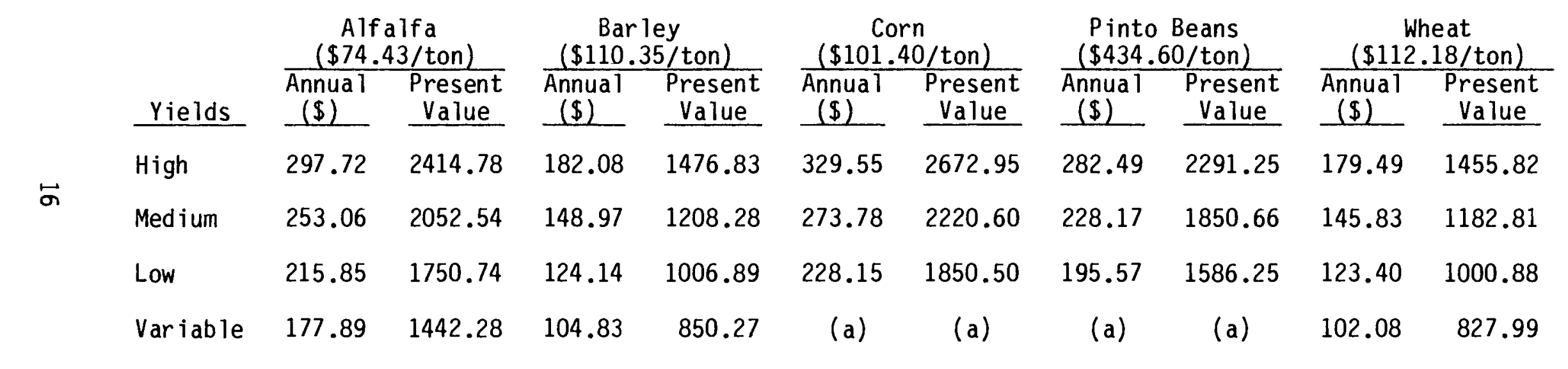

(a) Insufficient moisture available to support growth on slopes. 
value estimates are then calculated by applying the prices to the yield estimates given in Table 3. These income estimates are also presented in Table 4.

NET PRESENT VALUE OF CROPPING

Calculation of the net present value of the cropping alternatives involves summation of the present values of production costs and crop incomes. These estimates are shown in Table 5 for all of the yield levels and crops considered. On the basis of these calculations, it appears that wheat and barley production would not break even except at the higher yield levels. The other crops show positive net present values for all yield levels considered. These figures must be used with caution, however, since the yield estimates upon which they are based are highly uncertain. 
TABLE 5. Net Present Value of Cropping Activity Per Acre of Cropland (1979\$)

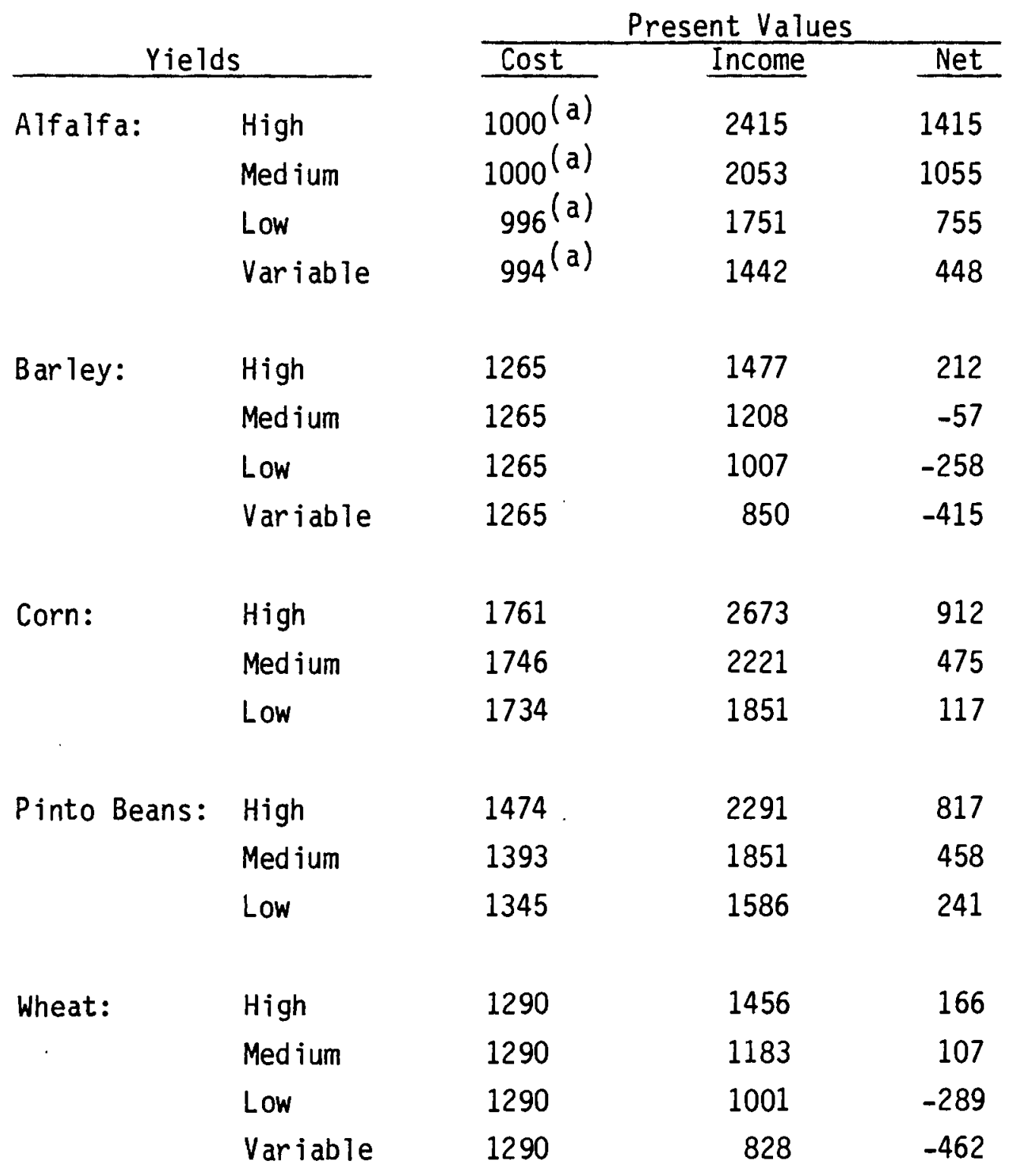

(a) Alfalfa cost estimates include establishment costs in the first and sixth years. 


\section{COMPARISON OF SYSTEMS}

The present values of the land reclamation costs and the net present values of the agricultural production associated with each of the reclamation systems are compared in this section. These present value estimates are based exclusively on private costs and income potential. Nonmarket costs and benefits, though possibly important, are beyond the scope of this study.

The operations involved in conventional reclamation are grading/leveling, contour disking, seeding, fertilizing, straw mulching, and reworking. The cost estimate for grading/leveling is $\$ 7,840$, and the contour disking, seeding, fertilizing, straw mulching, and reworking costs total $\$ 420$. Topsoiling is an additional $\$ 3000 /$ acre. Therefore, the cost present value to be compared with the PNL system's options is estimated to be $\$ 11,260 /$ acre.

Reclamation with the PNL system can be accomplished in two ways so two basic cost levels are considered. One way to reclaim the land is by treating the slopes to enhance water collection and growing crops only in the valleys. This approach has a grading/leveling cost of $\$ 5,190 /$ acre plus $\$ 2,000 /$ acre for topsoiling, plus initial slope treatment costs that vary from $\$ 0.00 /$ acre to $\$ 5,600 /$ acre. When maintenance costs are included, the present values of total slope treatment costs range from $\$ 7,365$ to $\$ 15,060$ per acre. The other way to reclaim the land involves planting crops on the slopes, so there are no slope treatment costs as such. However, more grading/leveling and spreading of topsoil is required, resulting in a cost present value of $\$ 8,950 /$ acre.

Table 6 summarizes all of the land reclamation costs associated with the two systems. It also shows the net present value of the income stream for each of the production and slope alternatives as well as for grazing. Three of the PNL system slope treatments have lower estimated costs than conventional reclamation. The difference is $\$ 3,895 /$ acre for compacted slope, $\$ 3,025 /$ acre for salt-compacted slope and $\$ 2,310 /$ acre for crop-on-slope. These differences constitute a substantial cost advantage for the PNL system on the basis of the present value of land reclamation and maintenance costs. 
TABLE 6. Present Value of Costs and Benefits of Reclamation Alternatives (1979 \$)

Reclamation

Alternatives

Costs/Acre

Grazing Ancome/Acre

Conventional

$\$ 11,260$

$\$ 0$

PNL:

\begin{tabular}{|c|c|c|c|c|c|c|c|}
\hline \multirow{3}{*}{$\begin{array}{l}\text { crop-on-slope } \\
\text { compacted (a) } \\
\text { salt (a) }\end{array}$} & $\$ 8,950$ & & $\$ 448$ & $\$-75$ & N.A. & N.A. & $\$-462$ \\
\hline & $\$ 7,365$ & $\int_{H}^{(b)}$ & $\$ 255$ & $\$ 38$ & $\$ 164$ & $\$ 147$ & 30 \\
\hline & $\$ 8,235$ & $M$ & $\$ 190$ & $\$-10$ & $\$ 86$ & $\$ 82$ & \\
\hline $\begin{array}{l}\text { paraff in (a) } \\
\text { asphalt (a) }\end{array}$ & $\begin{array}{l}\$ 13,170 \\
\$ 15,060\end{array}$ & $L$ & $\$ 136$ & $\$-46$ & $\$ 21$ & $\$ 43$ & $\$-52$ \\
\hline
\end{tabular}

(a) For the PNL system alternatives only $18 \%$ of the reclaimed land area is usable. Net income per acre of reclaimed land is $0.18 \%$ of income per acre of cropland.

(b) The income present value estimates are for high, H; medium, M; and Low, L, yields and apply to all four slope treatments.

The PNL system also has advantages based on the estimated value of agricultural production capacity. Even the lowest yield levels considered for alfalfa, corn and pinto beans had higher net present values than grazing. It is recognized, however, that both conventional and PNL reclamation may have nonmarket benefits that are not included in the benefit estimation. In order for the total net present value of conventional 1 and reclamation to equal the private benefits of the three cost-effective PNL options (crop-on-slope, compacted and salt-compacted slope), the present value of the nonmarket benefits from restoring land to original contour and use would have to be at least $\$ 2,760$ /acre $(\$ 11,260=\$ 8,950-\$ 448+\$ 2,758)$. While this analys is does not address the value of nonmarket benefits of wildlife habitat and other uses of rangeland, a study by Martin, Tinney and Gum (1978) does provide estimates of the value per square mile of land used for hunting in northeastern Arizona. Their estimate, though based on data for 1970 , is less than $\$ 1 /$ acre. Given this level of estimated benefits from use of the study area for hunting, it is unlikely that the total nonmarket benefits equal $\$ 2,760 /$ acre. 
APPENDIX A

CONVENTIONAL GRADING 
APPENDIX A

\section{CONVENTIONAL GRADING}

The shape and volume of spoil piles prior to reclamation is very important in determining reclamation costs. Variations in height and width of the piles affect the quantity of overburden to be moved and thus the costs of reclamation. To provide a basis for cost analysis, it is assumed that spoil piles are un iform in shape and have the following dimensions:

(1) Width of pile (base) $=40$ yards

(2) Original slope of spoil pile $=80 \%\left(38.6598^{\circ}\right.$ angle of repose)

Assuming that cross sections of the spoil piles are uniform triangles, the measurements (height, slope length, volume, etc.) of the spoil pile can be calculated (Watts 1975).

If the width of the original spoil pile's base $(B)=40$ yards, and the slope of the original spoil pile $(S)=80 \%$, the height of the original spoil pile $(H)=($ Tan $S$ degrees $)(1 / 2 B)=16$ yards, and the length of the slopes $(L)=$ square root of $\left(H^{2}+(1 / 2 B)^{2}\right)=25.6125$ yards. Thus, the original spo il piles have a 40-yard base, a 16-yard height, and a 25.6-yard-slope length as shown in Figure A.1.

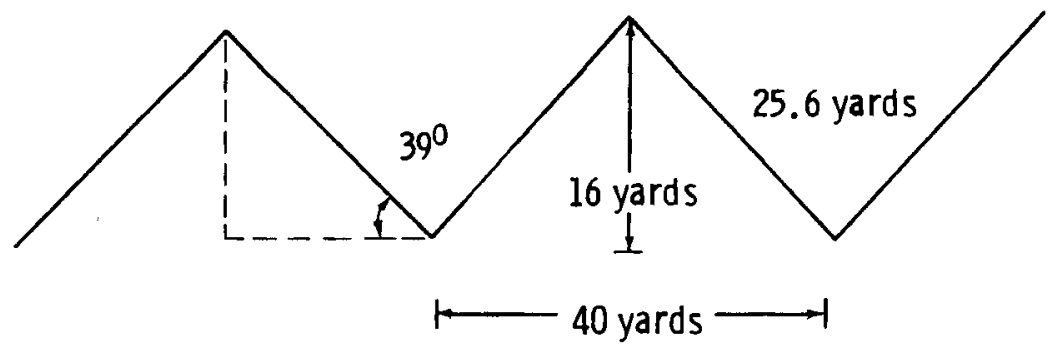

FIGURE A.1. Spoil Pile Dimensions

The cross-sectional area of an original spoil pile $(A)=1 / 2 \mathrm{~B} H=1 / 2$ $(40$ yards $)(16$ yards $)=320 y^{2}$. Multiplying by the length of the spoil piles per acre, a volume measure $\left(y d^{3}\right)$ is obtained, which is the most common measurement used in earth moving. The spoil pile length used in this study is 121 
yards. A spoil pile 40 yards wide and 121 yards long covers one acre of 1 and since $(121$ yards $)(40$ yards $)=4,840 \mathrm{yd}^{2}$.

In practice, the leveling of spoil piles produces a landscape of rolling contours, but to simplify this model it is assumed that the leveled surface will have distinct peaks and valleys, with a uniform slope of $1 \%\left(0.5729^{\circ}\right.$ angle of repose). To reach a level contour the top half ( 8 yards in height) of the spoil pile must be placed in the adjacent valley (see Figure A.2). This 8 yard height $(h)$ is used in the equations below.
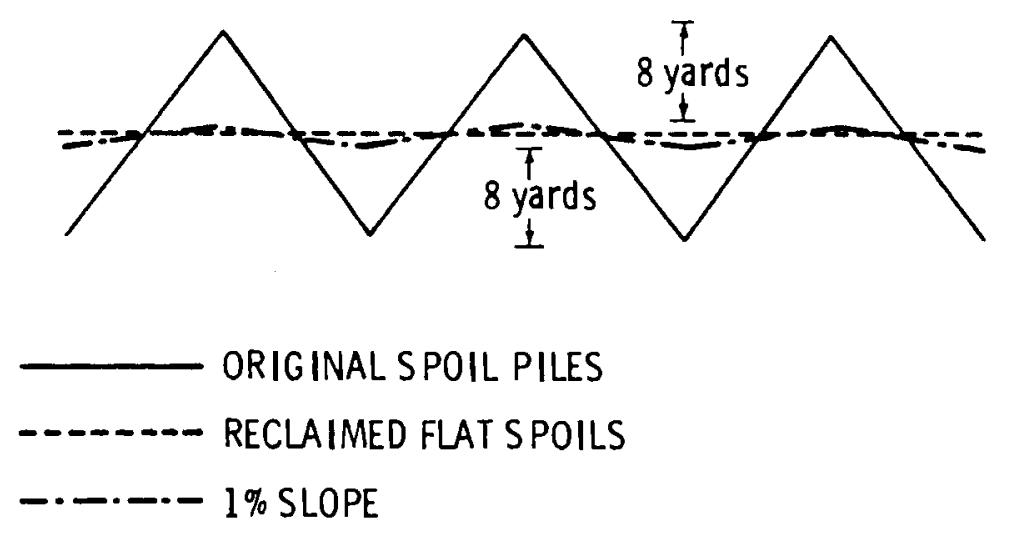

FIGURE A.2. Comparison of Reclaimed and Original Spoil Pile Contours

The equation, $A^{\prime}=h^{2} / S$, calculates the amount of overburden that must be moved to obtain a level contour. For this study, $A^{\prime}=(8)^{2} / 0.8=80 \mathrm{yd}^{2}$. Since we assume that there will be distinct peaks and valleys with a reclaimed slope of $1 \%$, there must be less material removed from the spoil pile and placed in the valleys than would be the case if a level contour were attached. The equation, $A^{\prime \prime}=h^{2}(R) / S^{2}$, estimates the amount of material that would be left on the spoil pile rather than moved. With a reclaimed slope $(R)$ of $1 \%, A^{\prime \prime}$ $=(8)^{2}(0.01) /(0.8)^{2}=1 y d^{2}$. Therefore, the amount of overburden that is moved $(T A)$ equals $A^{\prime}-A^{\prime \prime}$. Thus, $T A=80-1=79 \mathrm{yd}^{2}$. This figure is multiplied by the length of the pile to determine the cubic yards moved per acre of disturbed land using conventional reclamation practices $\left(79 \mathrm{yd}^{2} \times 121 \mathrm{yd}=\right.$ $\left.9559 \mathrm{yd}^{3}\right)$. 
APPENDIX B

GRADING COSTS 
APPENDIX B

GRADING COSTS

The costs of moving the overburden were estimated using Means' Building ' Construction Cost Data, 1980 and estimates of equipment usage provided by Mr. Hilgedick of Peabody Coal Company at Black Mesa. If the cost of using a dozer is $\$ 0.66 / \mathrm{yd}^{3}$, and the cost of using a scraper is $\$ 1.30 / \mathrm{yd}^{3}$, and their usage rates are 75 and 25 percent, respectively, their weighted average cost would be $\$ 0.82 / \mathrm{yd}^{3},\left(\$ 0.66 / \mathrm{yd}^{3}\right)(75 \%)+\left(\$ 1.30 / \mathrm{yd}^{3}\right)(25 \%)=\$ 0.82 / \mathrm{yd} \mathrm{d}^{3}$. It should be noted that this cost per $y d^{3}$ is a mine-specific estimate because the costs of using the equipment are location specific and the estimated equipment usages can vary between mine sites and companies. 


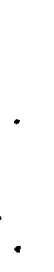


APPENDIX C

PNL GRADING 
APPENDIX C

PNL GRADING

To determine the amount of overburden leveled with the PNL system the same assumptions as made about the original spoil pile as for conventional reclamation. Differences exist, however, in the redistribution of stockpiled topsoil and in the angle of the reclaimed slope, which is $20 \%$, or $11.3^{\circ}$ for the PNL system. The goal of the PNL system is to provide flat valleys so that crops can be grown between the recontoured spoil pile slopes. Modified peaks and valleys are formed from the overburden and then topsoil is distributed to provide the flat valleys.

The configuration of the PNL system is shown in Figure D.1. Spoil pile peaks are reduced from their original height of 16 yards to a height of about 3 yards above the level of the 7 yard-wide cultivated areas. Grading required by the PNL reclamation system is calculated starting with the volume of overburden requiring movement to level the spoil piles. The equation for the crosssectional area affected is $A^{\prime}=h^{2} / S$. As in conventional reclamation $h=8$ $y d$ and $S$ (slope) $=0.8$, so the area involved is $80 \mathrm{yd}^{2}$. From this quantity we subtract the area of overburden ( $A^{\prime \prime}$ ) that would be left in place to create

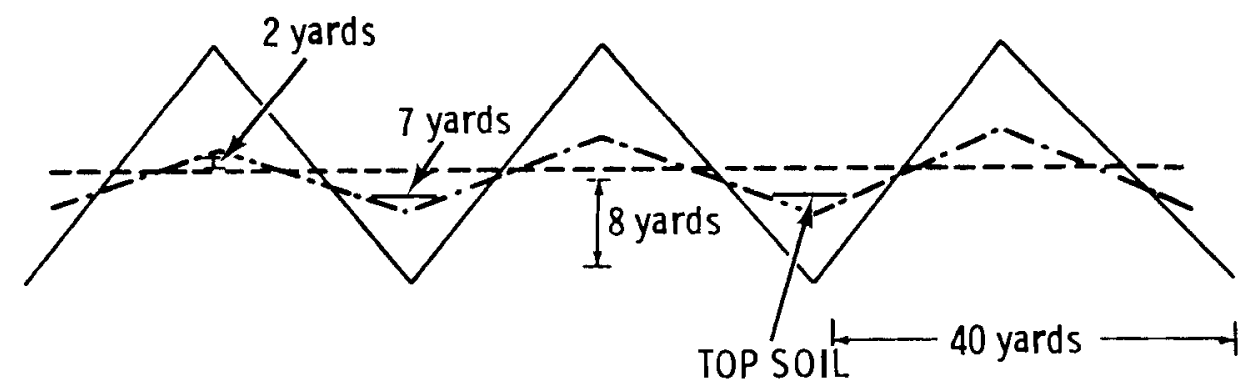

ORIGINAL SPOIL PILES

RECLAIMED FLAT SPOILS

-.-- PNL CONTOUR

FIGURE C.1. Comparison of PNL System and Original Spoil Pile Contours 
the 20\% slope required for the PNL system. The equation $A^{\prime \prime}=h^{2}(R) / S^{2}$ is used, where $R$ is the reclaimed slope. With a reclaimed slope of $20 \%, A^{\prime \prime}=$ $(8)^{2}(0.2) /(0.8)^{2}=20 \mathrm{yd}^{2}$ that can be left in position. Taking $A^{\prime}-A^{\prime \prime}$ leaves $60 \mathrm{yd}^{2}$ of overburden to be moved. This is multiplied by $121 \mathrm{yd}$ for a total of $7260 \mathrm{yd}^{3}$ of overburden to be moved per acre.

It is assumed that the amounts of topsoil available for both the conventional and PNL systems are the same. To cover one acre of leveled spoils 0.25 yards ( 9 inches) deep requires $1,210 \mathrm{yd}^{3}$ of topsoil, $(0.25 \mathrm{yd})(40 \mathrm{yd})$ $\left.(121 \mathrm{yd})=1,210 \mathrm{yd}^{3}\right)$. If this amount of topsoil were placed in the valley of the PNL system the valley width would be much greater than the needed 7 yards. To compensate for this, it is assumed that less overburden will be leveled off the original spoil piles so as to accomodate all of the topsoil in the valleys.

For the PNL system the amount of topsoil that would be required to fill in the valley to a 7 yard width is $\left.282 \mathrm{yd}^{3},\left(2.33 \mathrm{yd}^{2}\right)\left(121 \mathrm{yd}^{2}\right)=282 \mathrm{yd}^{3}\right)$. Since there would be $1210 \mathrm{yd}^{3}$ of topsoil available, $928 \mathrm{yd}^{3}$ of topsoil can replace movement of $928 \mathrm{yd}^{3}$ of overburden, 1,210 $\mathrm{yd}^{3}$ (total topsoil) -282 $\mathrm{yd}^{3}$ (topsoil needed to fill valley) $=928 \mathrm{yd}^{3}$. Thus, the amount of overburden requiring movement is reduced by $928 \mathrm{yd}^{3}$, from $7260 \mathrm{yd}^{3}$ to 6332 $\mathrm{yd}^{3}$. The resulting topsoil depth in the valleys would be about $4 \mathrm{ft}$, which should allow for dumping rather than even spreading of topsoil, which should reduce costs. 
APPENDIX D

SLOPE TREATMENT COSTS 
APPENDIX D

\section{SLOPE TREATMENT COSTS}

Initial costs of slope treatment are dependent on two major factors, the area of the slope and the type of slope treatment. For the PNL system contours described in Appendix $C$ the width of each reclaimed spoil pile slope is 16.5 yards. With two slopes to each spoil pile, the total width is 33 yards. Multiplying 33 yards by the 121 yard length gives a slope treatment area per acre of $3,993 \mathrm{yd}^{2}$.

Costs for five slope treatments that could be utilized with the PNL system (crop-on-slope, compacted slope, salt-compacted slope, paraffin treated slope, and rubber-asphalt treated slope) were analyzed in this study. Cost estimates were based on Cluff and Frobel's "Water Harvesting Catchment and Reservoir Construction Methods" for the salt-compacted treatment, a PNL cost study for the paraffin treatment, and communication with Sahuaro Petroleum and Asphalt Company on $8 / 12 / 80$ for the rubber-asphalt treatment. For the crop-onslope treatment, $7260 \mathrm{yd}^{3}$ of overburden would be moved to form $20 \%$ slopes and $282 \mathrm{yd}^{3}$ of topsoil would be placed to form 7 yd wide, flat valleys. The remaining $928 \mathrm{yd}^{3}$ of topsoil would be spread $4 \mathrm{in}$. deep over the slopes. Total cost of the treatment is $\left(7260 \mathrm{yd}^{3}\right)\left(\$ 0.82 / \mathrm{yd}^{3}\right)=\$ 5953+\$ 3000$ (topsoiling) $=\$ 8953 /$ acre. This is $\$ 176 /$ acre more then the basic PNL system (compacted slope) cost of $\$ 7190 /$ acre. All estimates are expressed in 1979 dollars and multiplied by the $3998 \mathrm{yd}^{2}$ of slope to be covered. These costs are shown in Table D.1.

The annual maintenance and periodic retreatment of slopes is expected to vary from year to year and from treatment to treatment. But in an attempt to generalize the analysis it was assumed that the different slope treatment costs would differ, but that the costs for a given treatment type would not vary between years. It was assumed that annual maintenance cost would equal a fixed percentage of the initial slope treatment cost and that retreatment would be required after 10 years. Table 0.2 shows these estimated annual maintenance costs and periodic retreatment costs for each slope treatment. 
TABLE D.1. Estimated Initial Slope Treatment Cost (1979\$)

$\begin{array}{lcc} & \frac{\$ / y d^{2}}{} & \$ / \text { acre } \\ \text { Crop-on-slope } & 0.44 & 1,760(a) \\ \text { Compacted slope } & 0.00 & 0(a) \\ \text { Salt-compacted slope } & 0.15 & 600 \\ \text { Paraffin treated slope } & 0.90 & 3,600 \\ \text { Rubber-asphalt treated slope } & 1.39 & 5,560\end{array}$

(a) Assuming no additional work or materials needed after grading/leveling.

The maintenance and retreatment costs are calculated using the cluff and Frobel (1978) report and the same square yardage figure, 3998, as was used to calculate initial slope treatment costs. The Cluff and Frobel (1978) report gave a range of estimates for slope treatment durability. For this analys is it was assumed that all slope treatments would have a life of ten years since ten years was within the predicted range for all treatments. Therefore, all estimated retreatment costs would occur after ten years. Though the initial slope treatment cost of the compacted slope is zero, it was assumed that annual maintenance would be 15 percent of what a "land clearing" (Cluff and Frobel 1978) slope treatment would cost.

TABLE D.2. Annual Maintenance and Retreatment Costs (1979\$)

\begin{tabular}{|c|c|c|c|c|c|}
\hline \multirow{2}{*}{$\begin{array}{l}\text { Slope } \\
\text { Treatment }\end{array}$} & \multirow{2}{*}{$\begin{array}{c}\text { Percent } \\
\text { of } \\
\text { Initial } \\
\text { Treatment } \\
\text { Cost } \\
\end{array}$} & \multicolumn{2}{|c|}{$\begin{array}{c}\text { Estimated } \\
\text { Annual } 1 \\
\text { Maintenance } \\
\end{array}$} & \multicolumn{2}{|c|}{$\begin{array}{c}\text { Est imated } \\
\text { Period ic } \\
\text { Retreatment } \\
\end{array}$} \\
\hline & & $\$ / y d^{2}$ & $\$$ /acre & $\$ / y d^{2}$ & $\$ /$ acre \\
\hline Crop-on-s lope & 0 & 0.00 & 0.00 & 0.00 & 0.00 \\
\hline Compacted slope & 15 & 0.0045 & 17.99 & 0.01 & 39.98 \\
\hline $\begin{array}{l}\text { Salt-comp acted } \\
\text { slope }\end{array}$ & 5 & 0.0075 & 29.97 & 0.0746 & 298.25 \\
\hline $\begin{array}{l}\text { Paraffin treated } \\
\text { slope }\end{array}$ & 5 & 0.045 & 179.91 & 0.34 & $1,359.32$ \\
\hline $\begin{array}{l}\text { Rubber-asphalt } \\
\text { treated slope }\end{array}$ & 1 & 0.0139 & 55.57 & 0.69 & $2,758.62$ \\
\hline
\end{tabular}


APPENDIX E

CROP PRODUCTION COSTS 


\section{CROP PRODUCTION COSTS}

The production costs of the five crops considered (alfalfa, barley, corn, pinto beans, and wheat) are estimated by using machinery costs from Graham County, Arizona (Hathorn 1980) and applying those costs to the series of operations required to produce each crop. While these machinery costs are not for Navajo County they are the most applicable available. All of the budgets developed are not shown, but a representative budget for each crop is presented. If the budget varies with yield (alfalfa, corn, pinto beans), the cost is presented for various yield levels. 
TABLE E.1. Costs for Alfalfa Hay, Baled (1979\$)

\begin{tabular}{|c|c|c|c|c|c|c|c|c|}
\hline \multirow[b]{2}{*}{ Operation } & \multicolumn{2}{|c|}{ Hours/Acre } & \multirow{2}{*}{$\begin{array}{l}\text { Mach ine } \\
\text { Fixed } \\
\text { Cost } \\
\end{array}$} & \multicolumn{4}{|c|}{ Variable Costs } & \multirow{2}{*}{$\begin{array}{l}\text { Tota } 1 \\
\text { Costs } \\
\end{array}$} \\
\hline & $\begin{array}{c}\text { Ma- } \\
\text { chine }\end{array}$ & Labor & & $\begin{array}{l}\text { Ma- } \\
\text { chine }\end{array}$ & Labor & Service & $\begin{array}{l}\text { Mate- } \\
\text { rials }\end{array}$ & \\
\hline Establishment & Costs: & & & & & & & \\
\hline $\begin{array}{l}\text { Broadcast } \\
\text { Fertilizer } \\
\text { Application }\end{array}$ & 0.225 & 0.250 & 2.71 & 3.71 & 1.13 & 0.00 & 28.08 & 35.63 \\
\hline Disking & 0.300 & 0.333 & 3.02 & 4.49 & 1.50 & 0.00 & 0.00 & 9.01 \\
\hline Plowing & 0.900 & 1.000 & 8.54 & 11.98 & 4.51 & 0.00 & 0.00 & 29.03 \\
\hline Planting & 0.300 & 0.333 & 7.91 & 4.92 & $\underline{1.50}$ & $\underline{0.00}$ & 48.05 & 62.38 \\
\hline TOTAL & & & 22.18 & 25.10 & 8.64 & 0.00 & 76.13 & 132.05 \\
\hline
\end{tabular}

Annual Costs:

\begin{tabular}{|c|c|c|c|c|c|c|c|c|}
\hline $\begin{array}{l}\text { Swathing } \\
\text { (2 times) }\end{array}$ & 0.675 & 0.750 & 18.67 & 10.55 & 3.38 & 0.00 & 0.00 & 32.60 \\
\hline $\begin{array}{l}\text { Raking } \\
\text { (2 times) }\end{array}$ & 0.360 & 0.400 & 2.76 & 4.40 & 1.80 & 0.00 & 0.00 & 8.96 \\
\hline $\begin{array}{l}\text { Baling } \\
\text { (2 times) }\end{array}$ & 0.675 & 0.750 & 8.28 & 9.15 & 3.38 & 0.00 & $\begin{array}{c}(0.45 / \\
\text { ton) }\end{array}$ & $\begin{array}{c}20.81+ \\
(0.45 / \\
\text { ton) }\end{array}$ \\
\hline $\begin{array}{l}\text { Roadsiding } \\
\text { (2 times) }\end{array}$ & 0.450 & 0.500 & $\underline{18.70}$ & 9.05 & $\underline{2.25}$ & $\underline{0.00}$ & 0.00 & 30.00 \\
\hline \multirow[t]{2}{*}{ TOTAL } & & & 48.41 & 33.15 & 10.81 & 0.00 & $\begin{array}{c}0.45 / \\
\text { ton }\end{array}$ & $\begin{array}{c}92.37+ \\
(0.45 / \\
\text { ton) }\end{array}$ \\
\hline & & & & \multicolumn{5}{|c|}{$\begin{array}{l}\text { High Yield }(8000 \mathrm{lb})=94.17 / \text { acre } \\
\text { Medium Yield }(6800 \mathrm{lb})=93.90 / \mathrm{acre} \\
\text { Low Yield }(5800 \mathrm{lb})=93.68 / \mathrm{acre} \\
\text { Variable Yield }(4780 \mathrm{lb})=93.45 / \text { acre }\end{array}$} \\
\hline
\end{tabular}


TABLE E.2. Costs for Barley (1979 \$)

\begin{tabular}{|c|c|c|c|c|c|c|c|c|}
\hline Operation & $\begin{array}{l}\text { Ma- } \\
\text { chine }\end{array}$ & Labor & $\begin{array}{l}\text { Fixed } \\
\text { Cost }\end{array}$ & $\begin{array}{c}\text { Ma- } \\
\text { chine }\end{array}$ & Labor & Service & $\begin{array}{l}\text { Mate- } \\
\text { rials }\end{array}$ & Costs \\
\hline Plowing & 0.900 & 1.000 & 8.54 & 11.98 & 4.51 & 0.00 & 0.00 & 25.03 \\
\hline Disking & 0.300 & 0.333 & 3.02 & 4.49 & 1.50 & 0.00 & 0.00 & 9.01 \\
\hline Planting & 0.300 & 0.333 & 7.14 & 4.46 & 1.50 & 0.00 & 53.82 & 66.92 \\
\hline Combining & 0.300 & 0.333 & 29.67 & 8.26 & 1.50 & 0.00 & 0.00 & 39.43 \\
\hline $\begin{array}{l}\text { Hauling } \\
\text { (10 miles) }\end{array}$ & 0.715 & 0.290 & 5.71 & 8.57 & 1.31 & $\underline{0.00}$ & 0.00 & 15.59 \\
\hline TOTAL & & & 54.08 & 37.76 & 10.32 & 0.00 & 53.82 & 155. \\
\hline
\end{tabular}


TABLE E.3. Costs for Corn (1979 \$)

\begin{tabular}{l} 
Operation \\
\hline Disking \\
Plowing \\
Herbicide \\
Application
\end{tabular}

Broadcast

Fertilizer Hours/Acre Machine

Ma- Variable Costs

Total chine Labor Cost chine Labor Service rials costs $\begin{array}{llllllll}0.300 & 0.333 & 3.02 & 4.49 & 1.50 & 0.00 & 0.00 & 9.01\end{array}$ $0.900 \quad 1.000$

8.54

11.98

4.51

0.00

$0.00 \quad 25.03$

$0.000 \quad 0.000$

0.00

$0.00 \quad 0.00$

2.75

$11.54 \quad 14.29$

$0.225 \quad 0.250$

2.71

$3.71 \quad 1.13$

0.00

28.08

35.63

Application

\begin{tabular}{|c|c|c|c|c|c|c|c|c|}
\hline $\begin{array}{l}\text { Injected } \\
\text { Fertilizer } \\
\text { Application }\end{array}$ & 0.180 & 0.200 & 4.68 & 2.32 & 0.90 & 0.00 & 26.88 & 34.78 \\
\hline Cultivation & 0.112 & 0.125 & 0.88 & 1.46 & 0.56 & 0.00 & 0.00 & 2.90 \\
\hline $\begin{array}{l}\text { Insecticide } \\
\text { Application }\end{array}$ & 0.000 & 0.000 & 0.00 & 0.00 & 0.00 & 2.75 & 11.13 & 13.88 \\
\hline Combining & 0.200 & 0.222 & 11.05 & 6.35 & 1.00 & 0.00 & 0.00 & 18.40 \\
\hline $\begin{array}{l}\text { Hauling } \\
\text { (10 miles) }\end{array}$ & 0.715 & 0.290 & 5.71 & 8.57 & 1.31 & 0.00 & 0.00 & 15.59 \\
\hline Drying & 0.000 & 0.000 & 0.00 & 0.00 & $\underline{0.00}$ & $\frac{(3.40 /}{\text { ton })}$ & $\underline{0.00}$ & $\frac{(3.40 /}{\text { ton })}$ \\
\hline \multirow[t]{2}{*}{ TOTAL } & & & 38.87 & 41.66 & 12.71 & $\begin{array}{r}5.50 \\
+(3.40 / \\
\text { ton })\end{array}$ & 107.37 & $\begin{array}{r}206.11 \\
+(3.40 / \\
\quad \text { ton })\end{array}$ \\
\hline & & & & \multicolumn{5}{|c|}{$\begin{array}{l}\text { High Yield }(6,5001 \mathrm{~b})=\$ 217.17 / \text { acre } \\
\text { Medium Yield }(5,4001 \mathrm{~b})=\$ 215.29 / \mathrm{acre} \\
\text { Low Yield }(4,5001 \mathrm{~b})=\$ 213.76 / \text { acre }\end{array}$} \\
\hline
\end{tabular}


TABLE E.4. Costs for Pinto Beans (1979\$)

\begin{tabular}{|c|c|c|c|c|c|c|c|c|}
\hline \multirow[b]{2}{*}{ Operation } & \multicolumn{2}{|c|}{ Hours/Acre } & \multirow{2}{*}{$\begin{array}{l}\text { Machine } \\
\text { Fixed } \\
\text { Cost } \\
\end{array}$} & \multicolumn{4}{|c|}{ Variable Costs } & \multirow{2}{*}{$\begin{array}{l}\text { Tota } 1 \\
\text { Costs } \\
\end{array}$} \\
\hline & $\begin{array}{l}\text { Ma- } \\
\text { chine }\end{array}$ & Labor & & $\begin{array}{l}\text { Ma- } \\
\text { chine }\end{array}$ & Labor & Service & $\begin{array}{l}\text { Mate- } \\
\text { rials } \\
\end{array}$ & \\
\hline Plowing & 0.900 & 1.000 & 8.54 & 11.98 & 4.51 & 0.00 & 0.00 & 25.03 \\
\hline Disking & 0.300 & 0.333 & 3.02 & 4.49 & 1.50 & 0.00 & 0.00 & 9.01 \\
\hline $\begin{array}{l}\text { Herbicide } \\
\text { Application }\end{array}$ & 0.000 & 0.000 & 0.00 & 0.00 & 0.00 & 2.75 & 5.85 & 8.60 \\
\hline Planting & 0.225 & 0.250 & 3.06 & 3.31 & 1.23 & 0.00 & 26.00 & 33.50 \\
\hline $\begin{array}{l}\text { Cultivation } \\
\text { (2 times) }\end{array}$ & 0.327 & 0.364 & 2.32 & 4.08 & 1.64 & 0.00 & 0.00 & 8.04 \\
\hline $\begin{array}{l}\text { Windrow \& } \\
\text { Cut }\end{array}$ & 0.000 & 0.000 & 0.00 & 0.00 & 0.00 & 15.00 & 0.00 & 15.00 \\
\hline Combining & 0.000 & 0.000 & 0.00 & 0.00 & 0.00 & 15.00 & 0.00 & 15.00 \\
\hline Hauling & 0.715 & 0.290 & 5.71 & 8.57 & 1.31 & 0.00 & 0.00 & 15.59 \\
\hline Cleaning & 0.000 & 0.000 & 0.00 & 0.00 & 0.00 & $\frac{(80.00 /}{\text { ton })}$ & $\underline{0.00}$ & $\frac{(80.00 /}{\underline{\text { ton })}}$ \\
\hline TOTAL & & & 22.65 & 32.43 & 10.09 & $\begin{array}{c}32.75+ \\
(80.00 / \\
\text { ton })\end{array}$ & $\begin{array}{r}31.85 \\
+\end{array}$ & $\begin{array}{c}129.77 \\
(80.00 / \\
\text { ton })\end{array}$ \\
\hline & & & & $\begin{array}{l}\text { igh } Y \\
\text { edium } \\
\text { OW Yie }\end{array}$ & $\begin{array}{l}(1,3 \\
l d(1 \\
900\end{array}$ & $\begin{array}{l}(b)= \\
01 b)= \\
=\$ 16\end{array}$ & $\begin{array}{l}77 / \mathrm{ac} \\
71.77 \\
/ \text { acre }\end{array}$ & \\
\hline
\end{tabular}


TABLE E.5. Costs for Wheat (1979 \$)

\begin{tabular}{|c|c|c|c|c|c|c|c|c|}
\hline \multirow[b]{2}{*}{ Operation } & \multicolumn{2}{|c|}{ Hours/Acre } & \multirow{2}{*}{$\begin{array}{c}\text { Mach ine } \\
\text { Fixed } \\
\text { Cost } \\
\end{array}$} & \multicolumn{4}{|c|}{ Variable Costs } & \multirow{2}{*}{$\begin{array}{l}\text { Tota } 1 \\
\text { Costs } \\
\end{array}$} \\
\hline & $\begin{array}{l}\text { Ma- } \\
\text { chine }\end{array}$ & Labor & & $\begin{array}{l}\text { Ma- } \\
\text { chine }\end{array}$ & Labor & Service & $\begin{array}{l}\text { Mate- } \\
\text { rials } \\
\end{array}$ & \\
\hline Plowing & 0.900 & 1.000 & 8.54 & 11.98 & 4.51 & 0.00 & 0.00 & 25.03 \\
\hline $\begin{array}{l}\text { Broadcast } \\
\text { Fertilizer } \\
\text { Application }\end{array}$ & 0.225 & 0.250 & 2.71 & 3.71 & 1.13 & 0.00 & 20.80 & 28.35 \\
\hline Disking & 0.300 & 0.333 & 3.02 & 4.49 & 1.50 & 0.00 & 0.00 & 9.01 \\
\hline Planting & 0.300 & 0.333 & 7.14 & 4.46 & 1.50 & 0.00 & 20.59 & 33.69 \\
\hline $\begin{array}{l}\text { Insecticide } \\
\text { Application }\end{array}$ & 0.000 & 0.000 & 0.00 & 0.00 & 0.00 & 2.75 & 5.20 & 7.95 \\
\hline Combining & 0.300 & 0.333 & 29.67 & 8.26 & 1.50 & 0.00 & 0.00 & 39.43 \\
\hline $\begin{array}{l}\text { Hauling } \\
\text { (10 miles) }\end{array}$ & 0.715 & 0.290 & 5.71 & 8.57 & 1.31 & $\underline{0.00}$ & $\underline{0.00}$ & 15.59 \\
\hline TOTAL & & & 56.79 & 41.47 & 11.45 & 2.75 & 46.59 & 159.05 \\
\hline
\end{tabular}




\section{REFERENCES}

Agricultural Marketing Service. 1979. Bean Market Summary, 1979. U.S. Department of Agriculture, Denver, Colorado.

Cluff, C. B. and R. K. Frobel. 1978. "Water Harvesting Catchment and Reservoir Construction Methods." Water Resources Contribution No. 2, Water Resources Research Center, University of Arizona, Tucson, AZ 85721.

Constant, C. L. and J. Thames. 1979. "Battelle Mound and Valley Water Harvesting System." Progress Report, School of Renewable Natural Resources, University of Arizona, Tucson, Arizona.

Dawson, D. 1980. "Compliance--The Coal Industry Experience." Peabody Coal Company, Flagstaff, Arizona.

Gisser, M., et al. 1979. Water: Agriculture Versus Energy Development in the Four Corners Area. LA-7643-MS, Los Alamos Scientific Laboratory, Los Alamos, New Mexico.

Godfrey, R. S., ed. 1979. Building Construction Cost Data, 1980. 38th Annual Edition, Means Company, Kingston, Massachusetts.

Hathorn, S., Jr. and R. Cluff. 1980. 1980 Arizona Field Crop Budgets: Graham County. Department of Agricultural Economics, University of Arizona, Tucson, AZ 85721.

Leathers, K. L. Costs of Strip Mine Reclamation in the West. Rural Development Research Report No. 19, U.S. Department of Agriculture, Washington, DC 20250 .

Martin, W. E., J. C. Tinney and R. L. Gum. 1978. "A Welfare Economic Analys is of the Potential Competition Between Hunting and Cattle Ranching." Western Journal of Agricultural Economics. 3(2):87-98.

Mayes, H. M., et al. 1980. Arizona Agricultural Statistics 1979. Bullet in S15, Arizona Crop and Livestock Reporting Service, Phoenix, AZ 85025.

Peabody Coal Company, Arizona Division. "Energy for Millions." Media information kit.

Persse, F. H., D. W. Lockard and A. E. Lindquist. 1977. Coal Surface Mining Reclamation Costs in the Western United States. Bureau of Mines Information Circular 8737, U.S. Department of Interior, Washington, D.C.

U.S. Department of the Interior, Bureau of Indian Affairs. 1964. Soil and Range Inventory of the-1882 Executive Order Area, Arizona. 
Verma, T. R., J. L. Thames and J. E. Mills. 1977. "Soil Erosion and Sediment Control on the Reclaimed Coal Mine Lands of Semi-Arid Southwest." in Hydrology and Water Resources in Arizona and the Southwest. Vol. 7, Proceedings of the 1977 meetings of the Arizona Section of the American Water Resources Association and the Hydrology Section of the Arizona Academy of Science, held in Las Vegas, Nevada, April 15-16, 1977.

Watts, M. J. 1975. Estimated Costs of Spoil Bank Reclamation Alternatives. Thes is, Montana State University, Bozeman, Montana. 


\section{BIBLIOGRAPHY ON MINED-LAND RECLAMATION}

Atwood, G. 1975. "The Strip Mining of Western Coal." Scientific American. $233(6): 23-29$.

Babcock, A. 1972. Spoil, Gob, and Fly Ash Produce Plant Supporting Soil. Technical Bulletin, No. 12, National Ash Association, Washington, D.C.

Barnhisel, R. I. 1977. Reclamation of Surface Mined Coal Spoils. PB-272 678, NTIS, Springfield, Virginia.

Beazley, R., C. L. Rogers and E. Ackerman. 1977. A Benefit-Cost System of Decision Making for Strip-Mined Land Reclamation in Illinois. I.I.E.Q., Doc. 77/22, I1lino is Institute for Environmental Quality, Chicago, IL 60606.

Carter, R. P., R. E. Z immerman and A. S. Kennedy. 1973. Strip Mine Reclamation in Illinois. Prepared for Illinois Institute for Environmental Quality by Argonne National Laboratory, Argonne, Illinois.

Catlett, L. and M. Boeh1je. 1979. "Strip-Mine Reclamation Laws and Regional Cost Implications." Southern Journal of Agricultural Economics. 11(1):157161 .

Chiron is, N. P., ed. 1978. Coal Age Operating Handbook of Coal Surface Mining and Reclamation. McGraw-Hill, New York, New York.

Cluff, C. B. 1980. Water Harvesting Systems: A Method of Reclamation for Mine Tailings. Presented at Mine Tailings Reclamation Workshop, Tucson, Arizona.

Cook, C. W., R. M. Hyde and P. L. Sims. 1974. Guidelines for Revegetation and Stabilization of Surface Mined Areas in the Western States. Range Science Series No. 16, Colorado State University, Fort Collins, Colorado.

Cook, C. W. 1976. "Surface-Mine Rehabilitation in the American West." Environmental Conservation. 3(3):179-183.

Energy and Environmental Analysis. 1976. Laws and Regulations Affecting Coal. U.S. Department of the Interior, Washington, D.C.

Energy and Environmental Analysis. 1977. Benefit/Cost Analysis of Laws and Regulations Affecting Coal. Prepared for Office of Minerals Policy and Research Analysis, U.S. Department of the Interior by Energy and Environmental Analysis, Arlington, Virginia.

Environmental Studies Board. 1974. Rehabilitation Potential of Western Coal Lands. Ballinger, Cambridge, Massachusetts.

Evans, A. K., E. W. Uhleman and P. A. Eby. 1978. Atlas of Western SurfaceMined Lands: Coal, Uranium, and Phosphate. FWS/OBS - 78/20, NALCO Environmental Sciences, Northbrook, Illino is. 
Gleason, V. E. 1979. Bibliography on Mined-Land Reclamation. Coal and the Environment Abstract Series. EPA-600/7-79-102, U.S. Environmental Protection Agency, Cincinnati, Ohio.

Gordon, R. L. 1975. Economic Analysis of Coal Supply: An Assessment of Existing Studies. EPRI 335, Electric Power Research Institute, Palo Alto, California.

Grandt, A. F. 1978. "Reclaiming Mined Land in Illino is for Row Crop Production." Journal of Soil and Water Conservation. September-October:242-244.

Grim, E. C. and R. D. Hill. 1974. Environmental Protection in Surface Mining of Coal. EPA-670/2-74-093, U.S. Environmental Protection Agency, Cincinnati, $\mathrm{OH} 45268$.

Guernsey, J. L., M. E. Tiller and J. R. LaFevers. 1977. Integrated Mine-Area Reclamation and Land Use Planning. Vol. 3D, ANL/EMR-1, Argonne National Laboratory, Argonne, AL 60439.

Kate11, S., E. L. Hemingway and L. H. Berkshire. 1976. Basic Estimated Capital Investment and Operating Costs for Coal Strip Mines. BuMines IC 8702, Revision of Information Circular 8661, U.S. Department of the Interior, Washington, D.C.

Lang, R., et al. 1975. Guildelines for Seeding Range Pasture, and Disturbed Lands. B-621, Agricultural Experiment Station, University of Wyoming, Laramie, Wyoming.

Leathers, K. L. 1980. Costs of Strip Mine Reclamation in the West. Rural Development Research Report No. 19, U.S. Department of Agriculture, Washington, DC 20250 .

Martin, W. E., J. C. Tinney, and R. L. Gum. 1978. "A Welfare Economic Analysis of the Potential Competition Between Hunting and Cattle Ranching." Western Journal of Agricultural Economics. 3(2):87-97.

Mathematica. 1976. Evaluation of Current Surface Coal Mining Overburden Handling Techniques and Reclamation Practice. Prepared for U.S. Department of the Interior, Bureau of Mines by Mathematica, Mathtech Division, Princeton, New Jersey.

McCarthy, R. E. 1975. "Land Reclamation, Water Quality Control and Environmental Concern at Centralia Washington Coal Mine." Practices and Problems of Land Reclamation in Western North America. University of North Dakota Press, Grand Forks, North Dakota.

National Coal Association. 1975. Third Symposium on Surface Mining and Reclamation, Volume 1. NCA/BCR, Coal Conference and Expo II, October 21-23, 1975. 
Nephew, E. A. and R. L. Spore. 1976. Costs of Coal Surface Mining and Reclamation in Appalachia. ORNL-NSF-EP-86, Oak Ridge National Laboratory, Oak Ridge, Tennessee.

Packer, P. E. 1974. Rehabilitation Potentials and Limitations of SurfaceMined Lands in the Northern Great Plains. General Technical Report, INT-14, USDA Forest Service, Intermountain Forest and Range Experiment Station, Ogden, Utah.

Patricoski, M. L., L. K. Daniels and A. A. Sobek. 1979. A Selective Bibliography of Surface Coal Mining and Reclamation Literature. ANL/LRP-1, Argonne National Laboratory, Argonne, Illinois.

Persse, F. H., D. W. Lockard and A. E. Lindquist. 1977. Coal Surface Mining Reclamation Costs in the Western United States. Bureau of Mines Information Circular 8737, U.S. Department of the Interior, Washington, D.C.

Randa11, A., et a1. 1978. "Reclamation Coal Surface Mines in Central Appalachia: A Case Study of the Benefits and Costs." Land Economics. $54(4): 472-489$.

Schol1, D. G. 1976. Laboratory Evaluation of Wax and Silicone for Water Harvesting on Coal Mine Spoil. USDA Forest Service Research Note RM-321, Rocky Mountain Forest and Range Experiment Station, Fort Collins, Colorado.

Scholl, D. G. and E. F. Aldon. 1979. "Water Harvesting to Establish Perennial Plants on Semiarid Coal Mine Spoil." in Ecology and Coal Resource Development, Volume 2. M. K. Wali, ed., Pergamon Press, New York, pp. 735-739.

School of Renewable Natural Resources. 1980. "Comprehensive Planning for Strip-Mine Reclamation in Dry Regions with Emphasis on Water Harvesting." Progress Report, submitted to Bureau of Mines, U.S. Department of the Interior by School of Renewable Natural Resources, University of Arizona, Tucson, Arizona.

Sindelar, B. W., R. L. Hodder and M. E. Majerus. 1973. Surface Mined Land Reclamation Research in Montana. Montana Agricultural Experiment Station.

Skelly and Loy. 1975. Economic Engineering Analys is of U.S. Surface Coal Mines and Effective Land Reclamation. BuMines OFR 74-75, U.S. Department of the Interior, Washington, D.C.

Surface Environment and Mining Program. 1979. User Guide to Vegetation, Mining and Reclamation in the West. General Technical Report INT-64, Intermountain Forest and Range Experiment Station, Ogden, Utah.

Techman. 1977. Materials Handling Methods for Plains Strip Mines. Vol. 1 and 2. Prepared for Land Conservation and Reclamation Division of the Alberta Department of Environment by Techman.

Thames, J. L., ed. 1977. Reclamation and Use of Disturbed Land in the Southwest. The University of Arizona Press, Tucson, Arizona. 
U.S. Department of the Interior. 1976. Resource and Potential Reclamation Evaluation, Foidel Creek Study Site. EMRIA, Report \#6, U.S. Department of the Interior, Washington, D.C.

U.S. Department of the Interior. 1976. Resource and Potential Reclamation Evaluation, Red Rim Study Area--Green River Coal Region. EMRIA, Report \#7, U.S. Department of the Interior, Bureau of Land Management, Bureau of Reclamation, Washington, D.C.

U.S. Department of the Interior. 1977. Resource and Potential Reclamation Evaluation, Bear Creek Study Area--West Moorhead Coalfield. EMRIA, Report \#8, U.S. Department of the Interior, Washington, D.C.

U.S. Department of the Interior. 1977. Resource and Potential Reclamation Evaluation, Horse Nose Butte Study Area--Dunn Center Lignite Field. EMRIA, Report \#9, U.S. Department of the Interior, Bureau of Land Management, Bureau of Reclamation, Washington, D.C.

University of Minnesota. 1976. "Reclamation and Revegetation of Strip Mined Land: A Selected B ibliography of Publications in the University of Minnesota Forestry Library." in Bibliography Series No. 1. PB-268-478, NTIS, Springfield, Virginia.

Verma, T. R. and J. L. Thames. 1975. "Rehabilitation of Land Disturbed by Surface Mining Coal in Arizona." Journal of Soil and Water Conservation. MayJune:129-131.

Verma, T. R., J. L. Thames and J. E. Mills. 1977. "Soil Erosion and Sediment Control on the Reclaimed Coal Mine Lands of Semi-Arid Southwest." in Hydrology and Water Resources in Arizona and the Southwest. Vol. 7, Proceedings of the 1977 meetings of the Arizona Section of the American Water Resources Association and the Hydrology Section of the Arizona Academy of Science, held in Las Vegas, Nevada, Apri1 15-16, 1977.

Vories, K. C., ed. 1976. Reclamation of Western Surface Mined Lands. Ecology Consultants, Inc.

Walsh, R. G. 1974. Some Benefits and Costs of Strip Mining Western Coal Resources. Great P1ains Agricultural Council, Publication No. 65, New Mexico Agricultural Experiment Station, New Mexico State University, Las Cruces, New Mexico.

Watson, J. L. 1979. Surface Mining Control and Reclamation Act. Energy Law Service Monograph 3A, Callaghan, Chicago, Illinois.

Watts, M. J. 1975. Estimated Cost of Spoil Bank Reclamation Alternatives. Thes is, Montana State University, Bozeman, Montana.

White, I. L., et al. 1979. Energy From the West: Policy Analys is Report. EPA-600/7-79-083, U.S. Environmental Protection Agency, Washington, D.C. 


\section{DISTRIBUTION}

No. of

Copies

OFFS ITE

A. A. Churm

DOE Patent Division

9800 S. Cass Avenue

Argonne, IL 60439

5 Dr. Ralph Franklin

DOE Office of Environmental Health and Research

Ecological Sciences Branch

Washington, DC 20545

Dr. Helen McCammon

DOE Office of Environmental Health and Research

Ecological Sciences Branch

Washington, DC 20545

27 DOE Technical Information Center

Dr. John Thames

School of Renewable Natural Resources

University of Arizona

Tucson, AZ 85721

Mr. Ralph Carter

Argonne National Laboratory

9800 Cass Avenue

Argonne, IL 60439

Dr. Gary McIntosh

U.S. Bureau of Mines

Building 20

Denver Federal Center

Denver, CO 80225
No. of

Copies

Wayne Hilgedick

Peabody Coal Company

P.0. Box 605

Kayenta, AZ 86033

2 Monte H. Marti

Department of Agricultural Economics Washington State University

Pullman, WA 99163

ONSITE

DOE Richland Operations Office

H. E. Ransom

27 Pacific Northwest Laboratory

K. E. Harding

P. M. Molton

L. A. Nieves (5)

W. H. Rickard

R. H. Sauer (5)

W. L. Templeton

M. L. Warner (5)

B. E. Vaughan

Publishing Coordination (2)

Technical Information KE (5) 


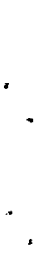

